DRAGANA TOMAŠEVIĆ PILIPOVIĆ ${ }^{*}$, BOŽO DALMACIJA ${ }^{1}$, ALEKSANDAR DOŠ $C^{2}$, ĐURĐA KERKEZ1', NATAŠA SLIJEPČEVIĆ ${ }^{1}$, MILENA BEČELIĆ-TOMIN ${ }^{1}$

${ }^{1}$ University of Novi Sad, Faculty of Sciences, Department for Chemistry, Biochemistry and Environmental Protection, Novi Sad, Serbia, ${ }^{2}$ University of East Sarajevo, Faculty of Technology, Zvornik, Republic of Srpska
Scientific paper

UDC:531.452(n)

doi:10.5937/ZasMat1503289T

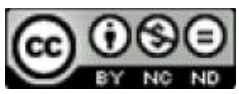

Zastita Materijala $56(3)$

289 - $296(2015$

\title{
Potential application of nanomaterials in the treatment of contaminated sediment
}

\begin{abstract}
In the conducted research nano zero valent iron has been used as the immobilization agent in the remediation treatment of dredged sediment, as well as the treatment that is performed on-site (in-situ). Study aims to find a better understanding of the behavior of metals in sediments and to determine their potential mobility, bioavailability and potential toxicity based on sequential extraction procedures. In order to evaluate the extraction potential of toxic metals and the effectiveness of the treatment applied, three single-step leaching tests were performed. When applying nanomaterial, as the immobilization agent in sediment treatment, using two remediation options (ex - situ and in - situ), high stability of the metals is achieved in treated sediment.
\end{abstract}

Keywords: kaolinite and bentonite coated nZVI, ex-situ and in-situ remediation, sediment.

\section{INTRODUCTION}

The rapid industrial development has greatly influenced the degradation of the environment, especially water resources, and therefore sediment. The need for analysis of sediment resulted from the fact that the sediment shows a strong tendency to bind and thus represents a reservoir of toxic and persistent compounds predominantly anthropogenic origin. Sediment disturbed by natural or human factor, may release pollutants into the water, and benthic organisms may be exposed through direct contact by entering the sediment, or by entering the dissolved pollutants present in the water. High concentrations of heavy metals in soils and sediments may cause long-term risks to ecosystems and humans. The total metal content in polluted environmental samples is a poor indicator of bioavailability, mobility or toxicity; these properties basically depend on the different chemical forms of binding between trace metals and solid phases of the samples [1].

In case where the sediment is contaminated, depending on the degree of pollution, remediation is sometimes necessary and it is not recommended

${ }^{*}$ Corresponding author: D. Tomašević Pilipović

E-mail: bozo.dalmacija@dh.uns.ac.rs

Paper received: 09. 02. 2015.

Paper accepted: 11. 04. 2015.

Paper is available on the website: www.idk.org.rs/casopis to disposed sediment on the controlled areas or as it is practice in our country, uncontrolled disposal on land. Selection of appropriate methods of sediment remediation depends on the specific characteristics of a given sediment, metal concentrations in individual fractions, the concentration and the type of pollutant that require elimination, as well as the final use of the contaminated sediments. However, it is necessary to take into account the high specificity of the sediment in the sample site ("site-specific"), so that required modifications will involve all relevant characteristics of a given place which affect the toxicity of metals.

Application of nanomaterials for environmental remediation has recently received great attention. Among the different nanomaterials, iron nano particles have been extensively studied to remediate pollutants such as organic compounds and metal ions. Nano zero valent iron $(\mathrm{nZVI})$ is a new material that is used for the sediment treatment, for remediation of dredged sediment, and when the treatment is performed on-site (in-situ). nZVI particles may range in diameter from 10 to 100 nanometers. They consist entirely of zero valent iron $\left(\mathrm{Fe}^{0}\right)$. Small particle size and high surface area make iron nanoparticle highly reactive and extremely volatile. Large surface area and surface reactions, as compared to a granular form, the nano particles allow remediation of contaminants at a higher rate and with a lower generation of hazardous by-products. Despite zero-valent iron nanoparticles ( $\mathrm{nZVI}$ ) being used to remediate both organic and inorganic 
contaminants in groundwater for over a decade, there are still technical challenges associated with its application. The application of unsupported nZVI and their agglomerates is complicated because of the extremely high pressure drops, lack of durability and mechanical strength in conventional systems [2]. To overcome this problem, various polymers and other coatings have been used to stabilize $n Z V I$ particles with varying degrees of success $[3,4]$.The coating of $n Z V I$ surface with polymers or polyelectrolyte provides increased steric and/or electrostatic repulsion between the nanoparticles. This has been shown to enhance their colloidal stability in water and decrease adhesion to porous media solids and thus increasing their potential for transport in porous media. The electrosteric stabilization offered by polyelectrolytes can overcome attractive van der Waals forces and magnetic forces between nZVI. More recently, clay-supported $\mathrm{nZVI}$ [5] have been used to remove metals and to reduce the extent of $n Z \mathrm{VI}$ aggregation.

Stabilization is one of the most effective methods to reduce the availability of toxic metal in soil by transforming toxic or potentially hazardous phases into less hazardous ones [6].

Leaching is known to be a complex phenomenon because many factors may influence the release of specific constituents from a waste over a period of time. Although numerous leaching tests are available to evaluate the stabilization treatment, no single test can describe the complex leaching behavior of treated materials, which creates confusion in how the results should be interpreted and which extraction test should be used in determining the leachability. Single extractions with water, diluted acetic acid, neutral salts and EDTA are generally performed in order to evaluate the proportion of metals weakly bound to the matrix, as a preliminary indication on the possible release of pollutants into the environment or their uptake by plants. In addition, sequential extractions are carried out with reagents of different chemical properties, in order to identify fractions of elements with different liabilities. Several sequential extraction schemes for metals have been developed; in particular, Tessier's scheme [7] is one of the most widely used and it has been extensively applied to aquatic sediments, soils and sludges. The sequential extraction procedure can be improved using microwave (MW) irradiation or its combination with ultrasonic shaking, to accelerate different chemical processes, including multi-step sequential extraction.

The paper investigates the possibility of using nano zero valent iron supported with bentonite and kaolinite for the immobilization of heavy metals, as well as the impact of nanomaterials on the behavior and fate of metals in the sediment. The main objectives of this study are assessing the characteristics of untreated and treated sediment and evaluating its environmental risk and evaluation of the effectiveness of stabilization treatment by assessing the leaching potential and environmental impact based on the different leaching procedures (TCLP, DIN 3841-4 S4, and SPLP).

\section{EXPERIMENTAL PART}

Kaolinite $(\mathrm{K})$ and bentonite $(\mathrm{B})$ samples containing nanometre-sized zero-valent iron particles were prepared using a conventional liquid-phase method by the reduction of ferric iron by borohydride in the presence of bentonite or kaolinite [8]. The weight ratio of bentonite to $\mathrm{nZVI}$ was $1: 1$, and the same ratio was used in kaolinite-supported $\mathrm{nZVI}$ as well. The concentration of iron in $1 \mathrm{~L}$ of solution was $14.000 \mathrm{ppm}$.

Kaolinite composition was (wt \%) $\mathrm{SiO}_{2}(45.9$ $\%), \mathrm{Al}_{2} \mathrm{O}_{3}(37.2 \%), \mathrm{Fe}_{2} \mathrm{O}_{3}(3.34 \%), \mathrm{MgO}(1.40 \%)$, $\mathrm{CaO}(0.25 \%), \mathrm{K}_{2} \mathrm{O}(0.14 \%), \mathrm{Na}_{2} \mathrm{O}(0.10 \%)$, ignition loss (13.3); bentonite composition was $\mathrm{SiO} 2$ (58.9), $\quad \mathrm{Al}_{2} \mathrm{O}_{3}$ (22.7), $\mathrm{Fe}_{2} \mathrm{O}_{3}$ (4.83), $\mathrm{MgO}$ (1.40), $\mathrm{CaO}$ (1.85), $\mathrm{K}_{2} \mathrm{O}(0.24), \mathrm{Na}_{2} \mathrm{O}(0.12)$, ignition loss (10.6).

Transmission electron microscope (TEM; Philis CM 10) and scanning electron microscope (SEM; Hithchi S-4700 Type II) images were recorded to determine the morphologies, size and particles distribution of the K-nZVI and B-nZVI. For scanning electron microscopy (SEM) images, powdered samples were first affixed onto adhesive tapes supported on metallic discs and then covered with a thin, electric conductive gold film. Images were recorded at different magnifications at an operating voltage of $30 \mathrm{kV}$. Structural analysis of K-nZVI and B-nZVI was performed using $77 \mathrm{~K} \mathrm{~N} 2$ adsorptiondesorption isotherms by Autosorb iQSurface Area Analyzer (Quantochrome Instruments, USA). Samples were outgassed at $120^{\circ} \mathrm{C}$ for $2 \mathrm{~h}$ before running isotherms. Multi-point Brunauer-Emmett-Teller (BET) method was used to determine specific surface area. Mesopore volumes were calculated from desorption isotherms using Barrett- JoynerHalenda (BJH) model and micropore volumes were calculated using $\mathrm{t}$ test method.

Mixtures for the ex-situ process were prepared by addition of $0.4,0.8$ and $1.2 \% \mathrm{nZVI}$ supported with bentonite and kaolinite as compared to the total weight of the sediment. The treated sediment samples were prepared by mixing with $B-n Z V I$ and $\mathrm{K}-\mathrm{nZVI}$ according to standard method ASTM D1557-00 [9] and cured at $20^{\circ} \mathrm{C}$ in sealed sample bags for 28 days.

Simulation of in-situ conditions was carried out by injection of nanomaterial in small vessels with $750 \mathrm{~g}$ of contaminated sediment. After injection of nanomaterials, with mixing of sediment it was performed a complete distribution of nanomaterials in the sediment. 
D. Tomašević Pilipović i dr. Potential application of nanomaterials in the treatment of contaminated ...

MWSE was performed for treated and untreated sediment samples as described by Jamali et al. [10], using identical operating conditions applied in each individual Community Bureau of Reference (BCR) fraction and validated by the CRM BCR 701.

Samples were then pulverized and subjected to various tests for leaching to determine the character of the final material. Tests used in this paper: Toxicity Characteristic Leaching Procedure-TCLP specially designed to mimic the acidic conditions of the sanitary landfill and to identify waste that has the potential to contaminate ground water [11]. German standard test- DIN 3841-4S4 [12] is used as a standard leaching test in determining the general characteristics of granular waste materials and sludge. Synthetic Precipitation Leaching Procedures -SPLP test [13] with a single extraction has been developed as an alternative to the TCLP test for situations where the waste is disposed outside of municipal landfill. Metal concentrations were determined by atomic absorption spectrometry AAS (Perkin ElmerAAnalyst ${ }^{\mathrm{TM}} 700$ ) using standard procedures.

\section{RESULTS AND DISCUSSION}

\section{Characterization of $K-n Z V I$ and $B-n Z V I$}

Kaolinite and bentonite were selected in order to represent the two extremes of physicochemical clay behaviour based on their surface area and CEC. The CEC (meq $100 \mathrm{~g}^{-1}$ ) was 19.1 for kaolinite and 70.4 for bentonite, while the respective surface areas $\left(\mathrm{m}^{2} \mathrm{~g}^{-1}\right)$ were 9.84 and 24.01 , so it can be concluded that bentonite has almost triple the BET specific surface area of kaolin. It is the total internal boundary between the solid phase and the pore system [14]. The multi-point BET specific surface areas of synthesized nanomaterials are significantly higher than those of the appropriate clays, for K-nZVI it is $14 \mathrm{~m}^{2} \mathrm{~g}^{-1}$ and for bentonite $40 \mathrm{~m}^{2} \mathrm{~g}^{-1}$. This suggests that the presence of zero-valent nanoparticles significantly increases the surface area, which is critical in high performance catalysts as the surface area of a porous material is one of the most useful microstructural parameters for defining its properties. From the aspect of mesopores (BJH model) there is almost no difference between kaolin $\left(0.031 \mathrm{~cm}^{3} \mathrm{~g}^{-1}\right)$ and bentonite $\left(0.032 \mathrm{~cm}^{3} \mathrm{~g}^{-1}\right)$.

The BJH total pore volume of synthesized nanomaterials increased in comparison with the appropriate clay, which attests to the presence of mesopores formed by the intercalated $\mathrm{Fe}$ nanoparticles. BJH for bentonite was $0.075 \mathrm{~cm}^{3} \mathrm{~g}^{-1}$ and for kaolinite $0.070 \mathrm{~cm}^{3} \mathrm{~g}^{-1}$. These findings are in good correlation with examinations conducted on similar materials $[14,15]$. In addition, only bentonite shows a micropore content (V-t method), $0.007 \mathrm{~cm}^{3}$ $\mathrm{g}^{-1}$. The larger surface area can contribute to more

uniform distribution of nZVI particles on the appropriate clays.

The physical shape and size of the synthesized $\mathrm{K}-\mathrm{nZVI}$ and $\mathrm{B}-\mathrm{nZVI}$ are presented in Fig. 1. The TEM and SEM images show the appearance of the small and clearly spherical particles. The particle sizes of the K-nZVI and B-nZVI, as measured from the images, varied between 20 and $90 \mathrm{~nm}$. These results proved that bentonite and kaolinite prevented the $n Z V I$ particles from aggregating together[16]. However, it can be seen that there is a difference between average nanoparticle sizes depending on the clay used. Nanoparticle size decreased in series of $80>30 \mathrm{~nm}$ when kaolin and bentonite were used for supporting $\mathrm{nZVI}$, indicating that there is a clear link between the dispersion of synthesized nano zerovalent iron particles and the BET specific surface area and porosity of the materials used for support as obtained by Tomasevic et al. [5] and Kerkez et al. [17].

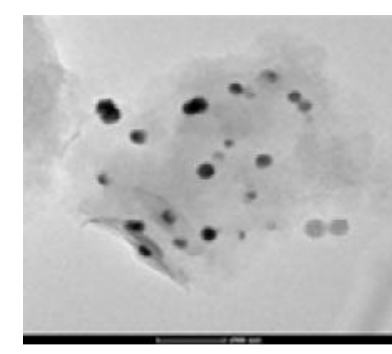

a)

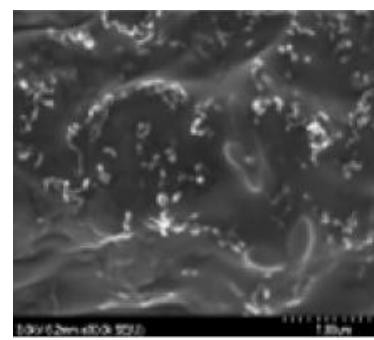

Figure 1 - SEM and TEM images of laboratorysynthesized iron particles with support material. a) Bentonite-nZVI and b) Kaolinite-nZVI

Pseudo-total metal concentrations and sequential extraction of untreated sediment sample

Pseudo-total concentrations of metals were: for Cr $420.2 \mathrm{mg} \mathrm{kg}^{-1}$, for Ni $471.4 \mathrm{mg} \mathrm{kg}^{-1}$, for Cu 394.1 $\mathrm{mg} \mathrm{kg}^{-1}$, for Zn $882.0 \mathrm{mg} \mathrm{kg}^{-1}$, for As $41.25 \mathrm{mg} \mathrm{kg}^{-1}$ and for $\mathrm{Pb} 394.1 \mathrm{mg} \mathrm{kg}^{-1}$ which, according to the Serbian regulation standards [18], is above intervention values and such sediment is considered severely polluted with analyzed metals (class 4) and needs dredging, disposal in special reservoirs and, if possible, sediment clean-up measures.

A sequential extraction procedure was utilized to divide the metals into four fractions: exchangeable and carbonate bound, iron and manganese oxides bound, organic matter bound and residual 
metal. The distribution of analyzed metals in differrent phases extracted by the MWSE procedure as described by Jamali et al. [10] is shown in Figure 2.

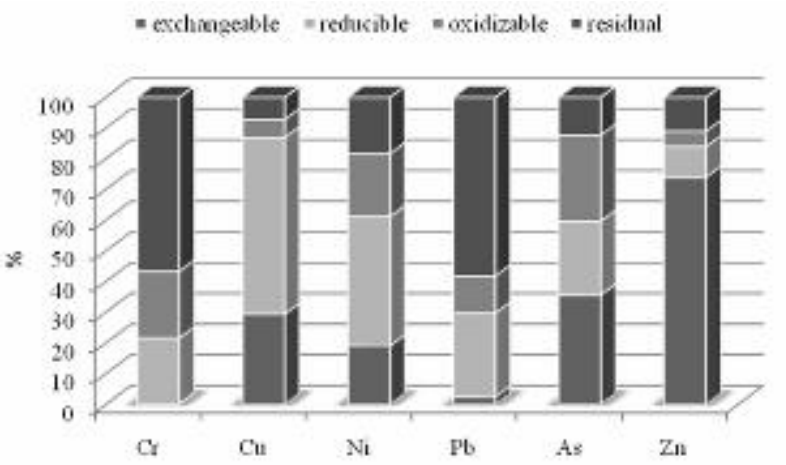

Figure 2 - Distribution of analysed metals in sequential extraction fraction of untreated sample

From Fig. 2, it can be seen that a high percentage of lead and zinc was found in the firstexchangeable fraction $(29.4 \%$ and $74.1 \%$, respectively). Metals in the exchangeable fraction can be exchanged and are in equilibrium with the ionic content in water. This fraction is sensitive to $\mathrm{pH}$ variations.

A significant proportion of $\mathrm{Ni}(57.4 \%)$ and $\mathrm{Cu}$ $(42.0 \%)$ were present in the third phase, the $\mathrm{Fe}-$ $\mathrm{Mn}$ oxides phase. The $\mathrm{Fe}-\mathrm{Mn}$ oxides fraction includes the soluble metal oxides/hydroxides under slightly acidic $\mathrm{pH}$ as well as the metal associated with reducible amorphous Fe-Mn oxyhydroxides. A significant proportion of $\mathrm{Pb}$ was also bound to organic matter $(28.0 \%)$. Oxidizing conditions lead to enhanced mineralization of organic matter, where there is a release of metals from these fractions.
Judging from the results of sequential extraction, arsenic and chromium are at the highest percentage (58.1 and $56.5 \%$, respectively) present in the fourth-residual phase which is the environmentally least dangerous phase, and hence cannot be considered as fully threatening to the environment.

A potential method to determine if the heavy metals can be removed by remediation techniques or predict removal efficiency is to determine speciation with selective extraction techniques. Although $\mathrm{Pb}$ and $\mathrm{Ni}$ speciation in the sediment were slightly different, we applied the same remediation treatment because there is not enough data about the behaviour of metals differently distributed in their mixture in sediment during their stabilization treatment, or about treatment efficiencies in general. The main objective of every remediation procedure dealing with several contaminants is to carry out the treatment with the same agents, and thus achieve economic and environmental benefits.

\section{Ex situ Treatment of contaminated sediment with $K-n Z V I$ and $B-n Z V I$}

Evaluation of metal toxicity in the sediment based on the sequential extraction procedure, after the treatment, indicated that the majority of metals after treatment are in oxide and residual phase. From Figure 3 the decrease immobility of $\mathrm{Zn}$ can be seen, with increasing percentage of added $\mathrm{K}$ $\mathrm{nZVI}$. If we compare the results with the results with the addition of the kaolinite and bentonite as immobilization agent [19], we come to the conclusion that the composition with the addition of much less nanomaterials gave similar results as the mixture with the addition of up to $30 \%$ kalinite and bentonite. a) $0.4 \% \mathrm{~K}$ -

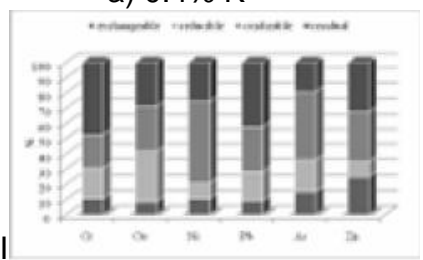

d) $0.4 \% \mathrm{~B}$ -

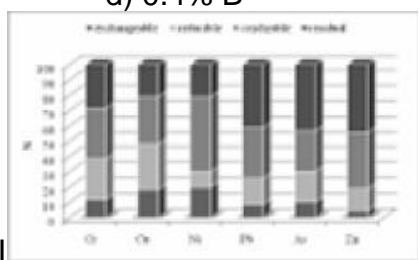

b) $0.8 \% \mathrm{~K}$ -

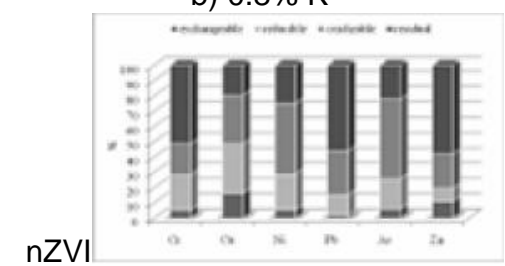

e) $0.8 \% \mathrm{~B}$ -

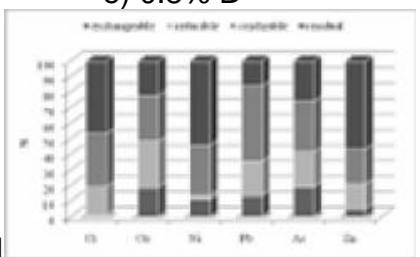

c) $1.2 \% \mathrm{~K}$ -

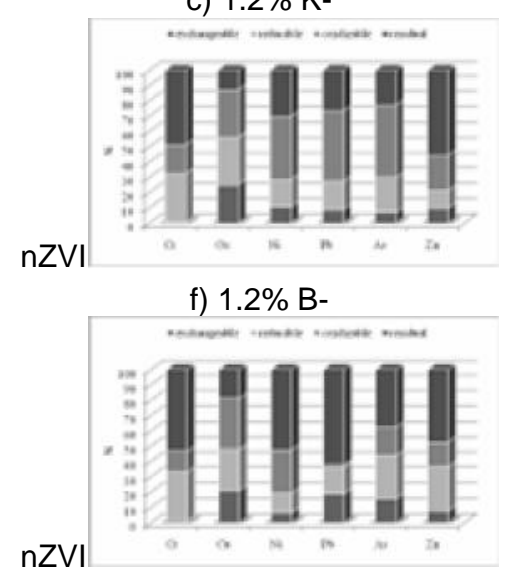

Figure 3 - Distribution of analysed metals in sequential extraction fraction of ex-situ treated sediment samples with addition of: a) $0.4 \%$, b) $0.8 \% \mathrm{~K}-n Z V I$, c) $1.2 \% \mathrm{~K}-n Z V I$, d) $0.4 \% \mathrm{~B}-n Z V I$, e) $0.8 \%$ B-nZVI, f) $1.2 \%$ B-nZVI

The results of TCLP, SPLP and DIN tests on treated samples are presented in Table 1. The ultimate leachable concentrations were compared with the limits regulated by the TCLP procedure [11], limit concentrations of metals in surface water according to current national regulations for water in third class [20], as well as the maximum permissible concentrations for inert waste [21], respectively.

The TCLP was specifically designed to mimic acidic conditions in a sanitary landfill and identify 
wastes that have the potential to contaminate ground water. All mixtures meet the TCLP test criteria in terms of the metal concentrations of regulated TCLP procedure for both bentonite and kaolinite supported nZVI treated samples.

SPLP is frequently used to assess the risk to groundwater posed by contaminated soils and in the risk assessment process for determining beneficial uses of solid wastes. SPLP test results show that metals concentrations in all mixtures are below the prescribed concentration limits for class III, according to the current national regulations [20]. The mixture with the highest content of immobilization agent for $\mathrm{As}, \mathrm{Cu}, \mathrm{Zn}$ and $\mathrm{Cr}$ met the limit values for class I, that responses excellent ecological status according to the classification given in the regulation.

Table 1 - Leached concentrations of toxic metals after TCLP, SPLP and DIN test of ex situ treated sediment sample and their comparison with relevant standards

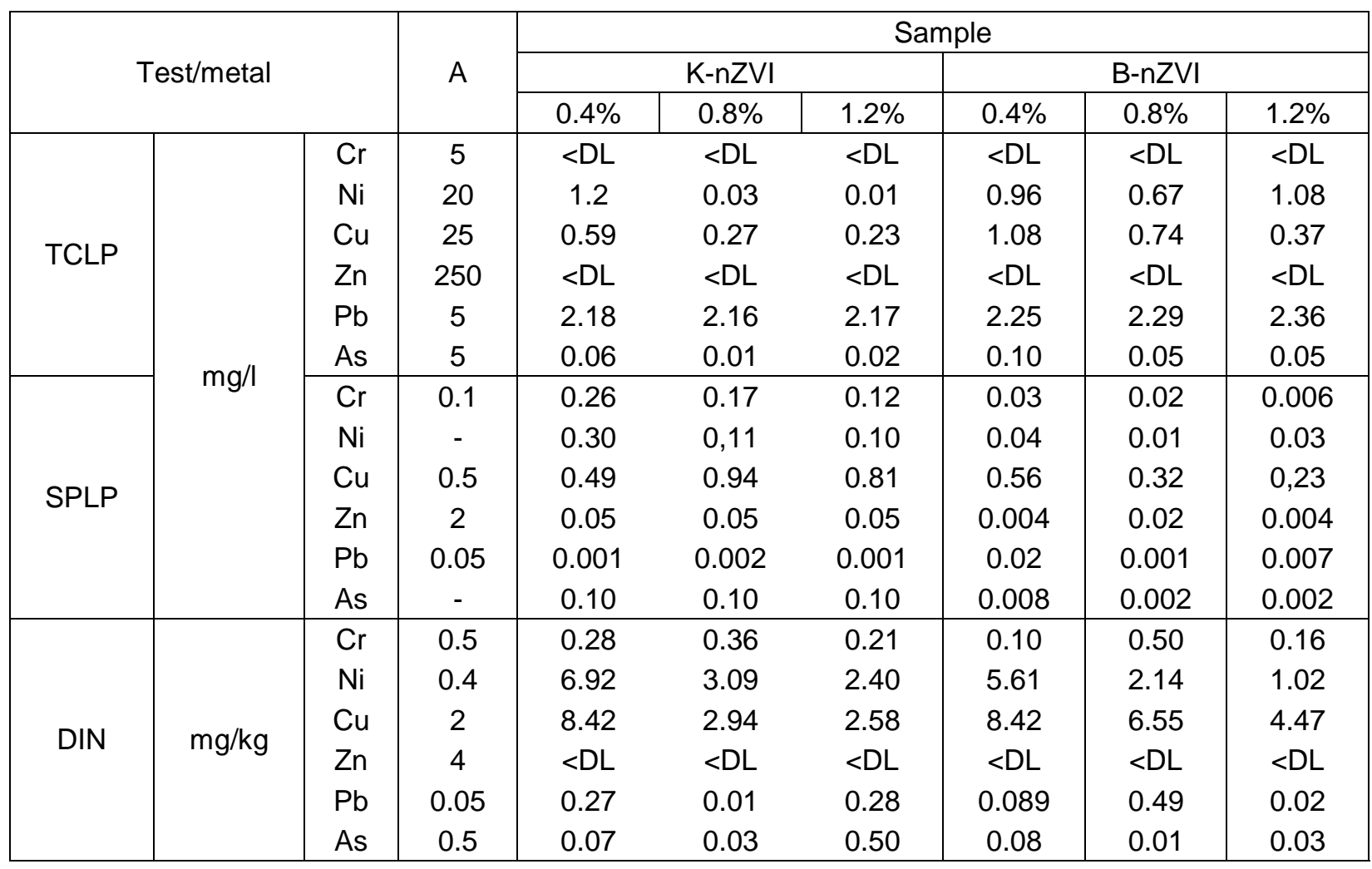

A: TCLP - Limit values for metals according to TCLP procedure [11]; SPLP - Emission limit values for waste water from surface waste disposal [20]; DIN - Maximum allowed concentration of accepting waste as inert [21]

Regarding the criteria for depositing prescribed in the Regulations on categories, testing and classification of waste [21], in terms of the concentration of $\mathrm{Cr}, \mathrm{Zn}, \mathrm{As}$ and $\mathrm{Pb}$ all mixtures can be considered as inert waste, while the concentration of $\mathrm{Cu}$ and $\mathrm{Ni}$ for all mixtures can be classified as non-hazardous waste.

In general it can be concluded that the mixture with B-nZVI are effective in immobilization of metal on each evaluated criteria in comparison to mixture with K-nZVI. Improved immobilization in the presence of B-nZVI can be explained by the presence of the montmorillonite in the bentonite, which is very reactive clay. Cation exchange capacity and the specific surface area of this clay are up to three times higher than kaolinite and therefore it has a greater affinity for the metal binding.

In situ Treatment of contaminated sediment with $K$ $n Z V I$ and $B-n Z V I$

The use of zero valent iron $\left(\mathrm{Fe}^{0}\right)$ in the in-situ remediation technique is currently undergoing evaluation. The basic mechanism for removal, originally suggested, involves the reduction of metal contaminants, then their subsequent precipitation of insoluble forms.

The sequential extraction procedure was applied to the mixture of sediment and both K-nZVI and B-nZVI after "aging" of 4 weeks (Figure 4). 
a) $0.4 \% \mathrm{~K}-$

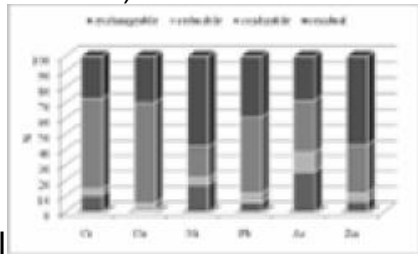

d) $0.4 \% \mathrm{~B}$ -

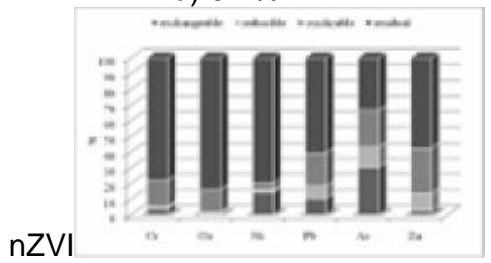

b) $0.8 \% \mathrm{~K}-$

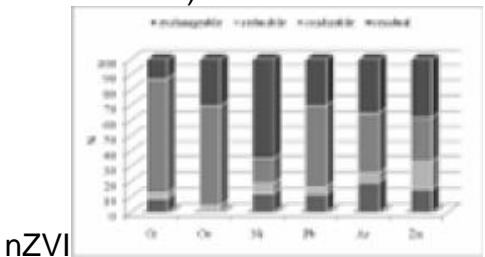

e) $0.8 \% \mathrm{~B}-$

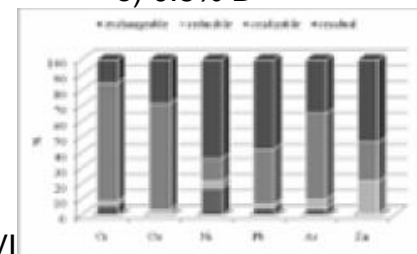

c) $1.2 \% \mathrm{~K}$

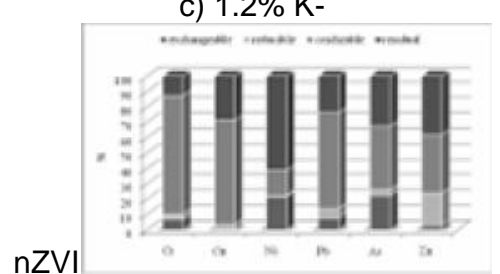

f) $1.2 \% \mathrm{~B}$ -

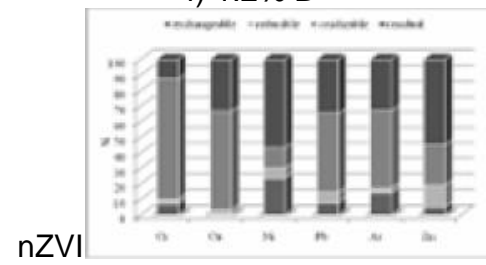

Figure 4 - Distribution of analysed metals in sequential extraction fraction of in situ treated sediment samples with addition of: a) $0.4 \%$, b) $0.8 \% \mathrm{~K}-n Z V I$, c) $1.2 \% \mathrm{~K}-n Z V I$, d) $0.4 \%$ B-nZVI, e) $0.8 \%$ B-nZVI, f) $1.2 \%$ B-nZVI

The figure clearly shows that there are no significant changes in the distribution of metals in phases, but after the addition of small amounts of immobilization materials, metals are mostly located in the third (oxidized) and fourth (residual) phase. If we compare the results of sequential extraction procedure of treated sediment with K-nZVI and B$\mathrm{nZVI}$ in in-situ treatment with the same mixtures in ex-situ treatment, we come to the conclusion that the in-situ treatment are better in terms of all metals, even with the addition of a minimum amount of immobilization agents. This can be explained with large reactivity of iron, even when it is supported, because it quickly oxidizes in air which is probably exactly what happened in ex-situ treatment.

TCLP test, SPLP test as well as German Standard DIN 38414-4 leaching test, were performed on mixtures after in-situ process after 4 weeks, and the results are shown in Table 2.

Table 2 - Leached concentrations of toxic metals after TCLP, SPLP and DIN test of in situ treated sediment sample and their comparison with relevant standards

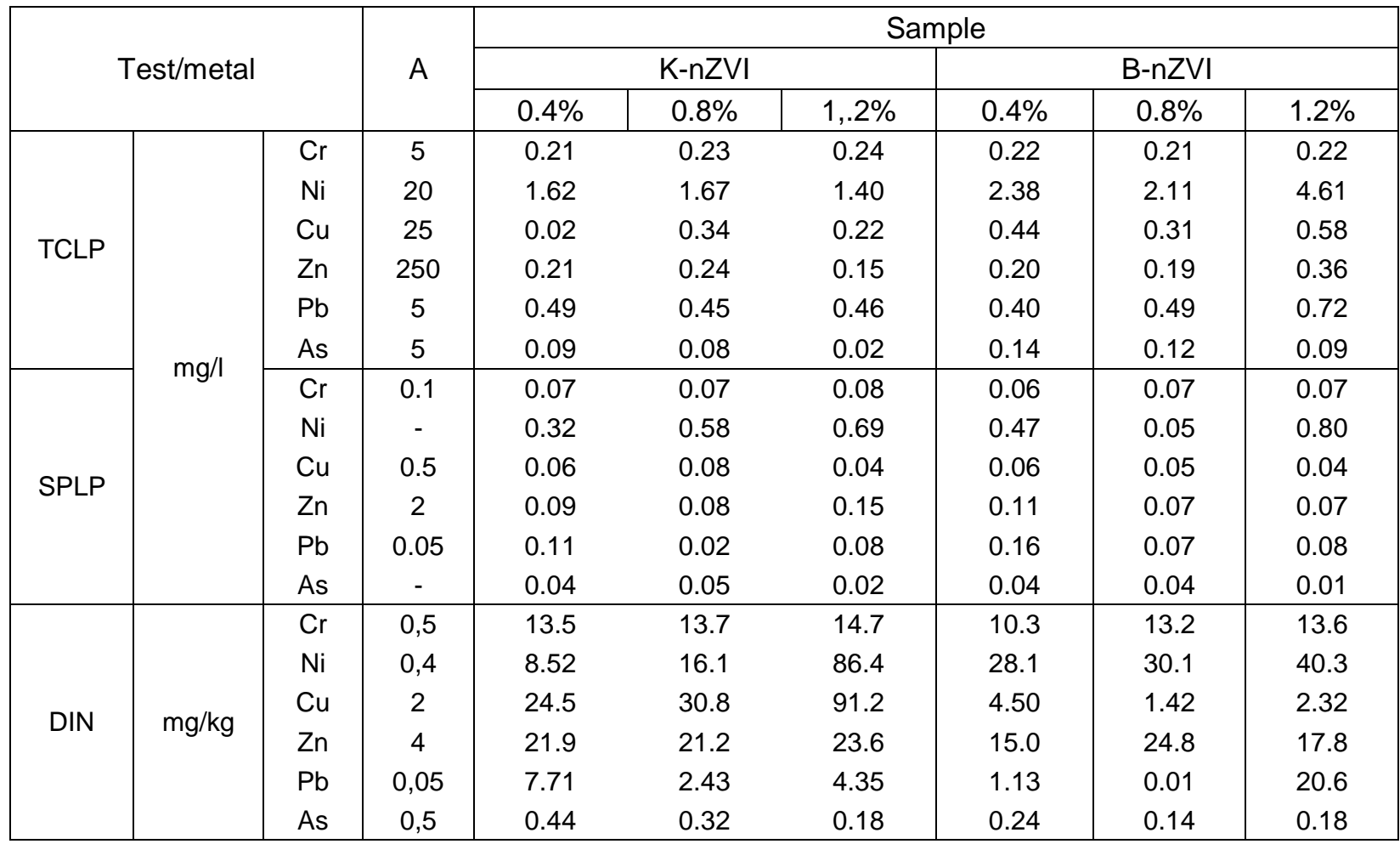

A:TCLP - Limit values for metals according to TCLP procedure [11]; SPLP - Emission limit values for waste water from surface waste disposal [20]; DIN - Maximum allowed concentration of accepting waste as inert [21] 
All mixtures met the criteria regulated by the TCLP procedure in terms of the leached concentration. SPLP test results show that the concentrations of $\mathrm{Cr}, \mathrm{Zn}, \mathrm{As}$ and $\mathrm{Cu}$, after treatment with $\mathrm{K}-\mathrm{nZVI}$, do not exceed the limit value for third class of water [20]. In the case where the in-situ treatment uses B-nZVI, concentrations of As, $\mathrm{Zn}, \mathrm{Cr}$ and $\mathrm{Cu}$ for all samples were below the limit concentration values of metal in the surface water level prescribed for the third class of water, while the concentration of $\mathrm{Zn}$ was below the limit values for the class II, with good water ecological status [20].

From the stand point of the Regulations on categories, testing and classification of waste [21], all metals in all mixtures can be classified as nonhazardous waste.

The impact of $\mathrm{pH}$ on metal removal by $\mathrm{nZVI}$ also depends on the oxidation state of the metal and the removal mechanism. Passivation of the $\mathrm{nZVI}$ surface at high $\mathrm{pH}$ hinders electron transfer from the $\mathrm{Fe}^{0}$ core, thus decreasing the removal of metal contaminants by reductive precipitation. High $\mathrm{pH}$ also decreases adsorption of metal anions due to electrostatic repulsion caused by the negative $\mathrm{nZVI}$ surface charge above a $\mathrm{pH}$ of 7.8 [22]. Oxidation and co-precipitation by iron oxides are the other possible reaction mechanisms depending upon the prevailing geochemical conditions such as $\mathrm{pH}$, Eh and initial concentration and speciation of contaminant metals.

Adsorption of both $\mathrm{As}^{3+}$ and $\mathrm{As}^{5+}$ on iron nanoparticles occurs by forming inner-sphere complexes with the (hydro) oxide shell of nZVI [22]. While reacting with $\mathrm{nZVI}, \mathrm{Pb}^{2+}$ precipitates as $\mathrm{Pb}(\mathrm{OH})_{2}$ and oxidizes as $\alpha-\mathrm{PbO}_{2}$ [23]. $\mathrm{Zn}$ may also be removed by precipitation on the oxidized $n Z \mathrm{VI}$ surface as $\mathrm{Zn}(\mathrm{OH})_{2}[24,25]$.

Consequently, each of these tests gives part of the answer needed to obtain an evaluation of the material properties relevant for an assessment of material behavior under field conditions

\section{CONCLUSIONS}

This work extends nanotechnology into stabilization of toxic metals in contaminated sediments. To reduce the leachability of toxic metals in sediment, nZVI supported with kaolinite and bentonite were synthesized as stabilization agents. Surface coating with kaolinite and bentonite prevented the nZVI particles aggregation and enhanced their mobility in soil media. Characterization of sediments contaminated with toxic metals, based on the pseudo-total content of arsenic, copper, chromium, lead, nickel and zinc, showed that the sediment can be considered toxic. Based on the above findings, the in-situ treatment in the laboratory proved to be very effective, providing the choice of optimal doses of nanomaterials towards the concentration of toxic metals in the sediment. TCLP, SPLP and DIN 3841-4 S4 tests applied to determine the potential leaching of metals, showed that in all stabilized mixtures, both in ex situ and in situ treatment, leaching of metals is very limited.

\section{Acknowledgement}

This work has been produced with the financial assistance of the EU (Project MATCROSS, HUSRB 1002/214/188) and the Ministry of Education, Science and Technological Development of the Republic of Serbia (Project Numbers III43005 and TR37004). The financial support of the TA MOP-4.2.2.A-11/1/KONV-2012-0047, TA' MOP4.2.2.A- 11/1/KONV-2012-0060 and OTKA NN 110676 projects is acknowledged. The contents of this document are the sole responsibility of the University of Novi Sad Faculty of Sciences and can under no circumstances be regarded as reflecting the position of the European Union and/or the Managing Authority.

\section{REFERENCES}

[1] K. Nemati, N.K. Abu Bakar, Mhd. Abas Radzi, E. Sobhanzadeh (2011) Speciation of heavy metals by modified BCR sequential extraction procedure in different depths of sediments from Sungai Buloh, Selangor, Malaysia. J. Hazard. Mater. 192, 402410.

[2] L. Cumbal, J. Greenleaf, D. Leun, A.K. SenGupta (2003) Polymer supported inorganic nanoparticles: characterization and environmental applications. React. Funct. Polym. 54, 167-180.

[3] F. He, D. Zhao (2005) Preparation and characterization of a new class of starch stabilized bimetallic nanoparticles for degradation of chlorinated hydrocarbons in water. Environ. Sci. Technol. 39, 3314-3320.

[4] F. He, D. Zhao (2007) Manipulating the size and dispersibility of zerovalent iron nanoparticles by use of carboxymethyl cellulose stabilizers. Environ. Sci. Technol. 41, 6216-6221.

[5] D. D. Tomašević, G. Kozma, Dj. V. Kerkez, B. D. Dalmacija, M. B. Dalmacija, M.R. Bečelić-Tomin, A. Kukovecz, Z. Konya, S. Rončević (2014) Toxic metal immobilization in contaminated sediment using bentonite- and kaolinite-supported nano zerovalent iron. J. Nanopart. Res. 16, 2548.

[6] T. Phenrat, T. Marhaba, M. Rachakornkij (2007) XRD and unconfined compressive strength study for a qualitative examination of calcium-arsenic compounds retardation of cement hydration in solidified/stabilized arsenic-iron hydroxide sludge. J. Environ. Eng. 133, 595-607.

[7] A. Tessier, P.G.C. Campbell, M. Bisson (1979) Sequential extraction procedure for the speciation of particulate traces metals. Anal. Chem. 51, 844-851.

[8] L. Shi, Y. Lin, X. Zhang, Z. Chen (2011) Synthesis, characterization and kinetics of bentonite supported 
$\mathrm{nZVI}$ for the removal of $\mathrm{Cr}(\mathrm{VI})$ from aqueous solution. Chem. Eng. J. 171, 612-617.

[9] ASTM Standard Test (2001) Method for Leaching Solid Waste in a Column Apparatus, ASTM D 4874, American Society for Testing and Materials, West Conshohocken, PA.

[10] M.K. Jamali, T.G. Kazi, M.B. Arain, H.I. Afridi, N. Jalbani, G.A. Kandhro, A.Q. Shah, J.A. Baig (2009) Speciation of heavy metals in untreated sewage sludge by using microwave assisted sequential extraction procedure. J. Hazard. Mater. 163, 11571164.

[11] U.S. EPA Method $1311 \quad$ (2003) Toxicity Characteristic Leaching Procedure, Test Methods for Evaluation of Solid Wastes, Physical/Chemical Methods, SW846, United States Environmental Protection Agency.

[12] DIN 38414-4 (1984) Teil 4: Schlamm und Sedimente, Gruppe S., Bestimmung der Eluierbarkeit mit Wasser S4, Beuth Verlag, Berlin.

[13] U.S. EPA Method 1312 (2003) Synthetic precipitation leachng procedure, Test Methods for Evaluation of Solid Wastes, Physical/Chemical Methods, SW846, United States Environmental Protection Agency.

[14] K.G. Bhattacharyya, S.S. Gupta (2006) Adsorption of chromium (VI) from water by clays. Ind. Eng. Chem. Res. 45 (21) 7232-7240.

[15] Y.H. Son, J.K. Lee, Y. Soong, D. Martello, M.K. Chyu (2012) Heterostructured zero valent ironmontmorillonite nanohybrid and their catalytic efficacy. Appl. Clay. Sci. 62-63, 21-26.

[16] O.B. Ayodele, B.H. Hameed, (2013) Development of kaolinite supported ferric oxalate heterogeneous catalyst for degradation of 4-nitrophenol in photoFenton process. Appl. Clay. Sci. 83-84,171-181.

[17] Dj. Kerkez, D. Tomašević, G. Kozma, M. BečelićTomin, M. Prica, S. Rončević, A. Kukovecz, B. Dalmacija, Z. Konya (2014) Three different clay-sup- ported nanoscale zero-valent iron materials for industrial azo dye degradation: a comparative study. J. Taiwan. Inst. Chem. Eng., doi:10.1016/ j.jtice.2014.04.019.

[18] Ministry of Natural Resources, Mining and Spatial Planning. Regulation on limit values for pollutants in surface, ground water and sediment and deadlines for their achievement. The Official, Gazette 35/2011 (in Serbian).

[19] M. Dalmacija, M. Prica, B. Dalmacija, S. Roncevic, M. Klasnja (2011) Quantifying the environmental impact of As and $\mathrm{Cr}$ in stabilized/solidified materials. Sci. Total. Environ. 412-413, 366-374.

[20] Official Gazette of RS, 67 (2011) and 48 (2012) Regulation on limit values of pollutants in water and deadlines for their achievement

[21] Official Gazette, Ministry of Energy, Development and the Environment, Regulation on categories, testing and classification of waste. The Official Gazette 56/2010, 2010.

[22] S.R. Kanel, D. Nepal, B. Manning, H. Choi (2007) Transport of surface-modified iron nanoparticle in porous media and application to arsenic(III) remediation. J. Nanopart. Res. 9, 725-735.

[23] H.L. Lien, Y.S. Jhuo, L.H. Chen, (2007) Effect of heavy metals on dechlorination of carbon tetrachloride by iron nanoparticles. Environ. Eng. Sci. 24, 21-30.

[24] W.L. Yan, A.A. Herzing, C.J. Kiely, W.X. Zhang, (2010) Nanoscale zero-valent iron (nZVI): aspects of the core-shell structure and reactions with inorganic species in water. J. Contam. Hydrol. 118, 96-104

[25] W.L. Yan, M.A.V. Ramos, B.E. Koel, W.X. Zhang, (2010) Multitiered distributions of arsenic in iron nanoparticles: observation of dual redox functionality enabled by a core-shell structure. Chem. Commun. 46, 6995-6997.

\section{IZVOD}

\section{POTENCIJALNA PRIMENA NANOMATERIJALA U TRETMANU KONTAMINIRANOG SEDIMENTA}

$U$ sprovedenom istraživanju je korišćeno $n$ no, nul $v$ lentno, gvožđe kao imobilizacioni agens $u$ tretmanu sedimenta, $k$ ko pri remedij ciji izmuljenog sediment, $t$ ko i pri tretm nu koji se vrši $n$ s moj lok ciji (in-situ). Studija ima za cilj da pronađe bolje razumevanje ponašanja metala u sedimentu i da utvrdi njihovu potencijalnu mobilnost, biodostupnost i potencijalnu toksičnost na osnovu sekvencijalne ekstrakcione procedure. Da bi se procenio potencijal izluživanja toksičnih metala i efikasnost postupka koji se primenjuje, izvedena su tri testa izluživanja u jednom koraku. Primenom nanomaterijala, kao imobilizacionog agensa u tretmanu sedimenta pomoću dve opcije remedijacije (ex-situ i in-situ), postignuta je visoka stabilnost metala u tretiranom sedimentu.

Ključne reči: kaolinit $i$ bentonit stabilizovano $n Z V I$, ex-situ i in-situ remedijacija, sediment.

Naučni rad

Rad primljen 09. 02. 2015.

Rad prihvacen 11. 04. 2015.

Rad je dostupan na sajtu: www.idk.org.rs/casopis 